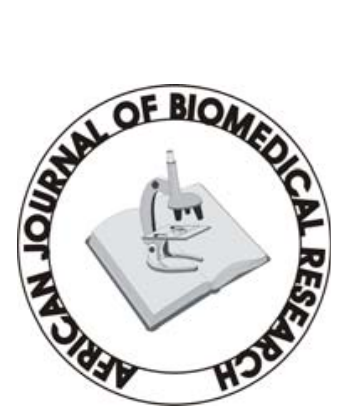

Full-text available at http://www.ajbrui.com http://www.bioline.br/md http://www.ajol.com

Received:

Accepted (Revised):

Published

Review Article

\title{
Phototherapy - a treatment modality for wound healing and pain relief
}

\section{Denise Hawkins and Heidi Abrahamse.}

Laser Research Group, Faculty of Health Sciences,University of Johannesburg, P.O. Box 17011,Doornfontein, Johannesburg, South Africa, 2028

\section{ABSTRACT}

When applied properly, phototherapy or Low Level Laser Therapy (LLLT) has proved to be very efficient in relieving pain and improving wound healing. However, until recently there has been a lack of scientific scrutiny concerning the clinical efficacy of this procedure. This does not mean that phototherapy does not work. A search for "laser" and "therapy" on the ISI Web of Knowledge database reported that the USA accounts for $35.69 \%$ of the research material while only 18 papers were reported from South Africa (1987-2006) which accounts for $0.17 \%$ of the 10652 papers analyzed. Despite the lack of scientific research, clinical results have been exceptional. Clinicians around the world, based on their professional experiences, confirm the analgesic effect of phototherapy. Unfortunately, from a strictly scientific point of view, these reports are hardly conclusive. There has been little or no standardization in the application of phototherapy. This review investigates key aspects of phototherapy and the efficacy of laser therapy for specific applications namely, wound healing and pain relief.

(Afr. J. Biomed. Res. 10:

Keywords: wound healing, pain relief, LLLT, phototherapy, laser

*Address for Correspondence: P.O. Box 17011, Doornfontein, South Africa 2028

TEL. +27 11 4068145, FAX. +27 11 4068202, e-mail: habrahamseuj.ac.za

Abstracted by:

African Index Medicus (WHO), CAB Abstracts, Index Copernicus, Global Health Abstracts, Asian Science Index, Index Veterinarius, Bioline International , African Journals online 


\section{INTRODUCTION}

The use of laser as a non-surgical medical treatment modality for assisting the normal processes of healing has increased over the last few years. However, the efficacy of laser in reducing pain or promoting tissue repair still remains controversial (Enwemeka et al, 2004). Laser therapy aims to restore the normal biological function of injured or stressed cells so 'Normalization' is the keystone of laser therapy (Tunér and Hode, 2002). The stimulatory effect of laser therapy can be seen in wounded cells or in cells that are growing suboptimally whereas cells that are normal or fully functional remain unaffected and no therapeutic effect can be observed (Smith, 1991).

\section{Photobiology}

Laser light has the unique properties of monochromaticity (a single wavelength), collimation (travels in a single direction without divergence) and coherence (with all waves in phase) (Matic et al, 2003). These properties are what allows laser light to penetrate the skin surface non-invasively (Matic et al, 2003; Theralase, 2003; Schindl et al., 1999). Therapeutic lasers are athermic with no appreciable heat transfer $\left(<0.65{ }^{\circ} \mathrm{C}\right)$ so the photonic energy is transferred directly to the target cells and thermal damage is avoided (Matic et al, 2003; Theralase, 2003). Therapeutic lasers use monochromatic light in the 630 to $905 \mathrm{~nm}$ range, known as the "therapeutic window" (Stadler et al, 2004).

Cellular effects of phototherapy can be classified into primary (light-induced), secondary (which occur in response to the primary effects) and tertiary effects (Schindl et al, 1999; Stadler et al, 2004; Dyson, 2006). Primary reactions are generally restricted to the absorption of photons while secondary effects are not unique to phototherapy and, because their occurrence depends on the sensitivity of the cells, are less predictable than primary effects (Dyson, 2006). Tertiary effects are the least predictable since the response is influenced by the internal and external environment and by intracellular interactions. The tertiary effect is also known as the systemic effect and explains why the treatment of one lesion can stimulate the healing of both the directly treated lesion and other lesions that the patient may have (Dyson, 2006).

In primary responses, photons emitted by the laser reach the mitochondria (Theralase, 2003) and cell membranes of low lying cells (fibroblasts, keratinocytes or endothelial) where the photonic energy is absorbed (Olsen et al., 1980) by chromophores (mitochondrial cytochromes, porphyrins and flavoproteins) and is converted to chemical kinetic energy (Matic et al, 2003) within the cell. This causes changes in membrane permeability, improved signaling between mitochondria, nucleus and cytosol, nitric oxide formation and increased oxidative metabolism to produce more ATP (Morimoto et al, 1994; Yu et al, 1997; Karu, 1989), which ultimately leads to normalization of cell function, pain relief and wound healing (Figure 1) (Matic et al, 2003; Dyson, 2006; Olsen et al, 1980).

Secondary reactions lead to the amplification of the above-mentioned primary photoreactions. A cascade of metabolic effects results in various physiological changes at the cellular level such as changes in cell membrane permeability (Figure 1) (Smith, 1991; Dyson, 2006; Olsen et al, 1980). Calcium is released from the mitochondria into the cytoplasm with changes in intracellular calcium levels (Tunér and Hode, 2002; Smith, 1991) which stimulates cell metabolism and the regulation of signaling pathways responsible for significant events required for wound repair such as cell migration, RNA and DNA synthesis, cell mitosis, protein secretion and cell proliferation (Takac and Stojanovic, 1998; Klepeis et al, 2001).

Tertiary effects are induced in cells at a distance from the cells in which the secondary events occur (Dyson, 2006). Irradiated or energized cells communicate with each other, and with nonirradiated cells, through increased levels of cytokines or growth factors (Smith, 1991; Vladimirov, 2004) resulting in inter-cellular communication (Tunér and Hode, 2002). There is an increase in the immune response with the activation of T-lymphocytes, macrophages and number of mast cells (Hamblin and Deidova, 2006). An increase in the synthesis of endorphins and decrease in bradykinin results in pain relief.

Studies have matched action spectra for biostimulation with absorption spectra of 
cytochrome c oxidase and have found remarkable similarities in the red and near- infrared (IR) regions of the spectrum (Hamblin and Deidova, 2006). All the individual oxidation states of the cytochrome c oxidase enzyme have different absorption spectra, thus probably accounting for differences in the action spectra of LLLT. The wavelength range important for phototherapy (600-860 nm) has four active regions, but peak positions are not exactly the same for all action spectra. The peak positions are between 613.5 and $623.5 \mathrm{~nm}$ (in one spectrum, at $606 \mathrm{~nm}$ ) in the red maximum. The far-red maximum has exact peak positions between 667.5 and 683.7 $\mathrm{nm}$ while two near-infrared maxima have peak positions in the range 750.7-772.3 nm and 812.5$846.0 \mathrm{~nm}$, respectively (Karu and Kolyakov, 2005).

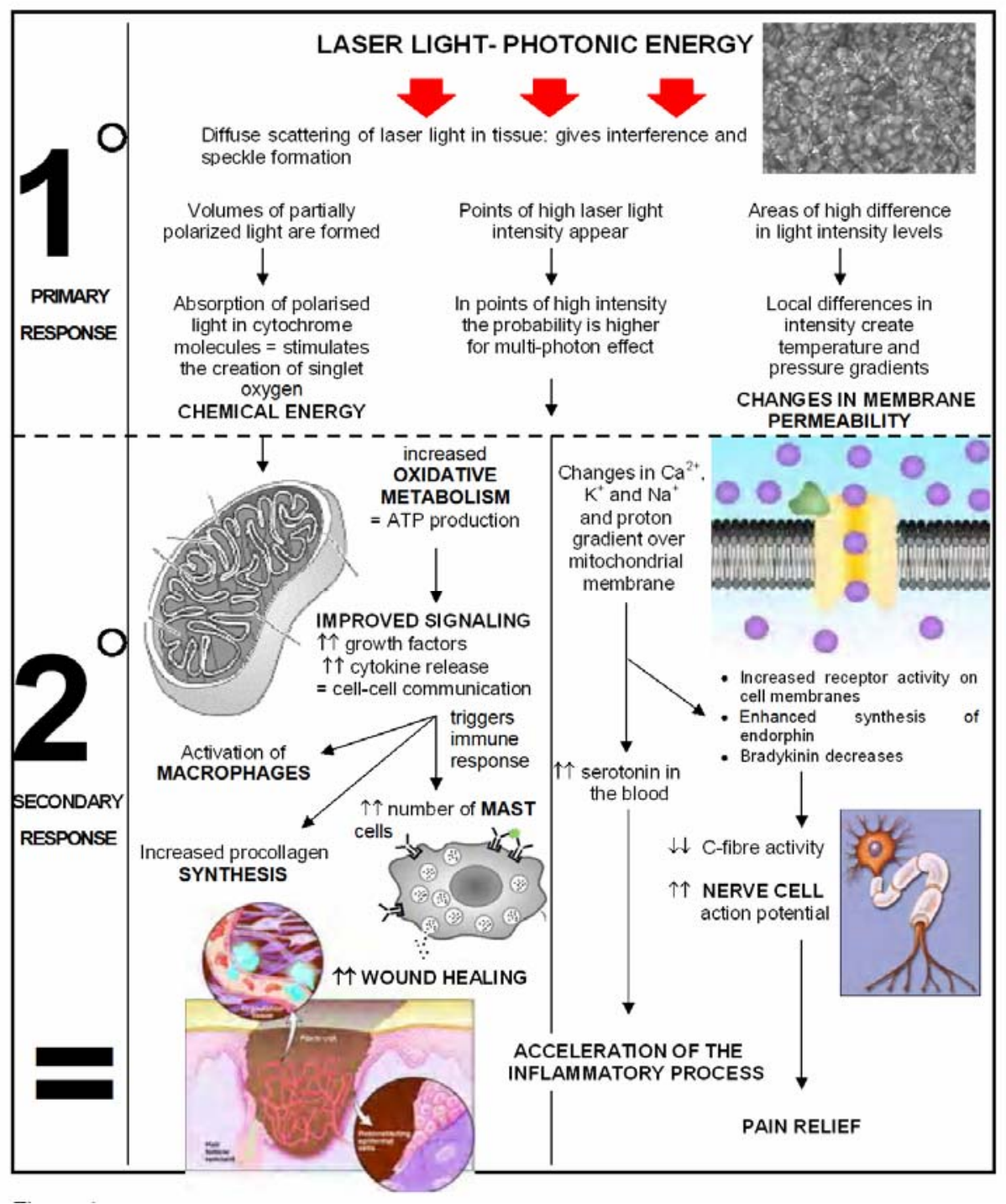

\section{Figure 1.}

The primary mechanisms relate to the interaction between photons and molecules in tissue, while the secondary mechanisms relate to the effect of the chemical changes induced by the primary effects. The stimulation of cellular ATP production has been suggested as one of the most important effects of laser therapy. The secondary mechanisms include effect on pain, effect on blood circulation, effect on stimulatory and regulatory mechanisms and effects on the immune system. Adapted and modified from the original text of Tunér and Hode (2002). 
Other mechanisms may be operating in LLLT. Certain molecules such as porphyrins can be converted into a long-lived triplet state after photon absorption. This triplet state can interact with ground-state oxygen with energy transfer leading to the production of a reactive singlet oxygen species (Hamblin and Deidova, 2006). Another proposed mechanism is the alteration of mitochondrial metabolism and activation of the respiratory chain by illumination, which would also increase production of superoxide anions $\mathrm{O}_{2}$. It has also been proposed that laser irradiation could reverse the inhibition of cytochrome c oxidase by nitric oxide (NO) and thus increase the rate of respiration with consequently more ATP synthesis (Hamblin and Deidova, 2006).

\begin{tabular}{|c|c|c|c|c|}
\hline & \multicolumn{2}{|c|}{ MINIMUM TREATMENT } & \multicolumn{2}{|c|}{ MAXIMUM TREATMENT } \\
\hline \multirow[t]{4}{*}{$\begin{array}{l}\text { Dose or } \\
\text { energy } \\
\text { density }\end{array}$} & & & & \\
\hline & \multicolumn{2}{|c|}{ Superficial wounds } & \multicolumn{2}{|c|}{ Musculoskeletal pain } \\
\hline & $\begin{array}{l}\text { Open wound } \\
\text { HeNe, } 632.8 \mathrm{~nm} \\
630 \mathrm{~nm}-700 \mathrm{~nm} \text { diode } \\
904 \mathrm{~nm} \text { GaAs } \\
\text { Wound periphery } \\
\mathrm{HeNe}, 632.8 \mathrm{~nm} \\
630 \mathrm{~nm}-700 \mathrm{~nm} \text { diode } \\
904 \mathrm{~nm} \text { GaAs }\end{array}$ & $\begin{array}{c}\mathrm{J} / \mathrm{cm}^{2} \\
0.5-1.5 \\
0.5-1.5 \\
0.01-0.2 \\
1-4 \\
2-6 \\
1-4\end{array}$ & $\begin{array}{l}\text { Chronic wound } \\
\text { HeNe, } 632.8 \mathrm{~nm} \\
\text { Wound periphery } \\
\mathrm{HeNe}, 632.8 \mathrm{~nm}\end{array}$ & $\begin{array}{c}\mathrm{J} / \mathrm{cm}^{2} \\
3-4\end{array}$ \\
\hline & $\begin{array}{l}\text { Superficial pain } \\
\text { HeNe, } 632.8 \mathrm{~nm} \\
630 \mathrm{~nm}-700 \mathrm{~nm} \text { diode } \\
904 \mathrm{~nm} \mathrm{GaAs}\end{array}$ & $\begin{array}{c}0.5-2 \\
1-4 \\
2-4\end{array}$ & $\begin{array}{l}\text { Deep lying pain } \\
904 \mathrm{~nm} \text { GaAs } \\
870 \mathrm{~nm} \text { GaAlAs }\end{array}$ & $\begin{array}{l}2-5 \\
4-10\end{array}$ \\
\hline $\begin{array}{l}\text { Continuous } \\
\text { vs pulsed }\end{array}$ & \multicolumn{2}{|c|}{$\begin{array}{c}\text { HeNe } 632.8 \mathrm{~nm} \text { - continuous } \\
\text { GaAs } 904 \mathrm{~nm} \text { - pulsed } \\
\text { Pulsed: use average output power } \\
\text { to calculate dose }\end{array}$} & \multicolumn{2}{|c|}{$\begin{array}{c}\text { GaAlAs } 780,820,870 \mathrm{~nm}- \\
\text { continuous } \\
\text { W: use output power to calculate } \\
\text { dose }\end{array}$} \\
\hline $\begin{array}{l}\text { Wavelength } \\
\text { of probe }\end{array}$ & \multicolumn{2}{|c|}{$\begin{array}{c}\text { Superficial wound, < penetration, } \\
\text { visible light probe } \\
(632.8 \mathrm{~nm}, 660 \mathrm{~nm})\end{array}$} & \multicolumn{2}{|c|}{$\begin{array}{c}\text { Deep wound, > penetration, } \\
\text { musculoskeletal injury, infrared } \\
\text { probe (904 nm) }\end{array}$} \\
\hline $\begin{array}{l}\text { Contact vs } \\
\text { non-contact }\end{array}$ & \multicolumn{2}{|c|}{$\begin{array}{l}1-2 \mathrm{~cm} \text { from the wound and the } \\
\text { periphery of the wound is treated in } \\
\text { skin contact. } \\
\text { For superficial problems the probe is } \\
\text { held in light contact with the skin }\end{array}$} & \multicolumn{2}{|c|}{$\begin{array}{l}\text { For medium or deep problems the } \\
\text { probe is held with pressure in } \\
\text { direct contact with the skin to } \\
\text { increase the penetration depth. }\end{array}$} \\
\hline Pigmentation & \multicolumn{2}{|c|}{$\begin{array}{l}\text { Light complexion - better } \\
\text { penetration }\end{array}$} & \multicolumn{2}{|c|}{$\begin{array}{l}\text { Dark complexion - absorbs the } \\
\text { light and reduces penetration }\end{array}$} \\
\hline $\begin{array}{l}\text { Treatment } \\
\text { area }\end{array}$ & \multicolumn{2}{|c|}{$\begin{array}{l}\text { Muscle, bone, ligament - better } \\
\text { penetration }\end{array}$} & \multicolumn{2}{|c|}{$\begin{array}{l}\text { Adipose or highly vascular tissue } \\
\text { - reduces penetration. Deeper } \\
\text { tissues require more treatment }\end{array}$} \\
\hline $\begin{array}{l}\text { Treatment } \\
\text { interval }\end{array}$ & \multicolumn{2}{|c|}{$\begin{array}{c}\text { Acute wounds or musculoskeletal } \\
\text { injury - daily } \\
\text { Every third day for } 2 \text { weeks then } \\
\text { once a week for a few weeks. }\end{array}$} & \multicolumn{2}{|c|}{$\begin{array}{l}\text { Chronic wounds or injury }-1 \text { or } 2 \\
\text { weekly } \\
\text { Infected ulcers - twice weekly until } \\
\text { infection clears }\end{array}$} \\
\hline
\end{tabular}

Figure 2.

Key aspects of phototherapy that can be used to establish an effective therapeutic regimen for the treatment of superficial wounds or skin conditions and musculoskeletal injuries. 
Key aspects that influence phototherapy can be used as guide to establish an effective therapeutic regimen for the treatment of superficial wounds or skin conditions and musculoskeletal injuries (Figure 2). Some of the key aspects include:

Lasers: Diode lasers emit light with a shorter coherence length than Helium-Neon (HeNe, $632.8 \mathrm{~nm}$ ) lasers and the biological effects of light from a $633 \mathrm{~nm}$ diode laser are less obvious than those from a HeNe laser. A diode laser can obtain similar results by using a higher power output (25$50 \mathrm{~mW}$ ) and higher doses (Tunér and Hode, 2002; Ohshiro and Calderhead, 1988).

Wavelength: Wavelength is the distance between two peaks of a wave. The symbol for wavelength is $\lambda$ (lambda) and the unit of measurement is nanometers (nm) (Peavy, 2002). The penetration of laser light depends on the wavelength, the output power and the treatment technique used. (Tunér and Hode, 2002; Theralase, 2003; Pontinen, 1992).

Power: The unit of power is Watt (W) and since the laser output power is low it is expressed in milliwatts (mW) (Peavy, 2002). The power density or light intensity of the beam on the tissue surface is expressed in $\mathrm{mW} / \mathrm{cm}^{2}$ which is the power divided by the area of the target tissue being illuminated by the laser light (Schindl et al, 1999; van Breugal and Dop Bar, 1992). The stronger the power output (mW) the shorter the treatment time.

Energy density: (dose or fluence) is expressed in Joules per $\mathrm{cm}^{2}\left(\mathrm{~J} / \mathrm{cm}^{2}\right)$, which is the product of power $(\mathrm{mW})$ and time $(5)$ per spot size $\left(\mathrm{cm}^{2}\right)$ (Tunér and Hode, 2002; Ohshiro and Calderhead, 1988). The dose administered is influenced by the power, time, irradiance (power density) and treatment intervals but the dose required depends on the wavelength, type of tissue, condition and depth of target tissue, chronic or acute problem, pigmentation and treatment technique (contact versus non-contact) (van Breugal and Dop Bar, 1992; Woodruff et al, 2004; Baxter et al, 1997). Biostimulatory studies report using doses from as low as $0.001 \mathrm{~J} / \mathrm{cm}^{2}$ to 10 $\mathrm{J} / \mathrm{cm}^{2}$ however effective doses of near-IR light may be much higher than $10 \mathrm{~J} / \mathrm{cm}^{2}$ especially for deep lesions. Doses that are too low result in a weak effect with no observable effect. If a dose above the highest one suitable is administered (van Breugal and Dop Bar, 1992), a negative or minimal effect is detected. With an even greater dose, a biosuppressive or inhibitory effect may be observed (Coombe et al, 2001). In treatment, the dose is often referred to as the number of Joules per point where a point is defined as an area that is $5 \mathrm{~mm}$ in diameter $\left(0.2 \mathrm{~cm}^{2}\right)$ or less.

Continuous versus pulsed wave technology: A light source that emits light at a constant intensity is known as continuous wave (CW) emission whereas pulsed light has varying intensity (Ohshiro and Calderhead, 1988). When a laser is pulsed, the laser light power varies between the pulse peak output power and zero so the average power is used to calculate the dose while continuous wave lasers use the output power $(\mathrm{mW})$.

Contact versus non-contact: A laser can be used in a scanning mode or in contact with the surface of the skin, with or without pressure and held flat against the skin or with the aperture protruding (Ohshiro and Calderhead, 1988; Pontinen, 1992). In order for a laser system to provide optimal penetration through the skin it must be in direct contact with the skin and at an incident angle of 90 degrees (perpendicular to the skin) (Ohshiro and Calderhead, 1988; Mendez et $a l, 2004)$. This will minimize any reflection from the skin's surface and allow the best penetration into the tissue.

\section{Therapeutic applications}

Several studies have demonstrated either a stimulatory or inhibitory effect of phototherapy on healing mechanisms using in vitro cell culture studies (van Breugal and Dop Bar, 1992). In vivo studies have demonstrated that phototherapy has a positive effect on wound healing in the clinical environment; however the exact mechanism is still not completely understood since a specific therapeutic window, dosimetry or mechanism of action has not been determined (Smith, 1991; Coombe et al, 2001; Karu et al, 1984). The effect on the patient and how it effects healing has however been well documented but the lack of knowledge complicates the evaluation of conflicting reports found in literature (Tunér and Hode, 2002). Lack of quality control has produced negative results in some studies and criticism of many of the positive 
studies (Tunér and Hode, 2002). Studies claim that laser therapy dramatically reduces healing time compared to other traditionally used modalities. Hospitals in the UK use laser therapy in postsurgical recovery rooms and have found that patients have less pain, take $50 \%$ less pain medication, heal in half the time and have significantly less scar tissue (Rudnick, 2005). However, Allendorf et al, (1997) reported that HeNe laser irradiation $\left(1 \mathrm{~J} / \mathrm{cm}^{2}\right.$, $2 \mathrm{~J} / \mathrm{cm}^{2}$ and $4 \mathrm{~J} / \mathrm{cm}^{2}$ ) had no measurable benefit on wound healing and a biostimulatory mechanism could not be elucidated. Likewise, Colver and Priestley (1989) concluded that HeNe (633 nm, 5 $\mathrm{mW}, 1 \mathrm{~mm}$ diameter beam) laser irradiation (three times a day for 3 days) did not have any significant effect on cell proliferation.

Trelles et al, (1989) reviewed the use of local irradiation with phototherapy and found this approach elicited the following types of effects: biostimulatory, analgesic, anti-exudative, antihaemorrhagic, anti-inflammatory, anti-neuralgic, anti-oedematous, anti-spasmotic and vasodilatory. Furthermore, Medrado et al, (2003) studied the effect of LLLT on wound healing and concluded laser therapy reduced the inflammatory reaction and increased collagen deposition with a greater proliferation of myofibroblasts in experimental cutaneous wounds. Both studies found the main clinical uses of LLLT included wound healing, pain control, soft tissue injury, arthropathy, osteopathy and treatment of existing scars (Medrado et al, 2003; Trelles et al, 1989).

Some of the clinical effects of phototherapy are that it:

1. reduces pain in a large variety of acute and chronic pain entities including pain related to abnormalities in nerves, soft tissue, muscles, tendons, joints and bone.

2. reduces swelling and inflammation associated with acute injuries in superficial muscles, tendons, ligaments, bursae, and sheaths (Smith, 1991; Woodruff eta!, 2004; de Freitas et al, 2001),

3. improves wound healing of slow-to-heal or nonhealing wounds in soft tissues, tendons and bone due to improved tissue oxygenation and nutrition (Takac and Stojanovic, 1998; Woodruff et al, 2004; Kubota, 2004; Gabel,
1995),

4. improves absorption of interstitial fluid (antioedematous) and increases lymphatic circulation and drainage which results in better tissue regeneration (Takac and Stojanovic, 1998),

5. improves local and systemic blood circulation which is useful in blood-related conditions such as Buerger's and Raynaud's diseases and torpid leg ulcers,

6 enhance autoimmune response in immunedeficient conditions such as psoriasis, rheumatoid arthritis and atopic dermatitis (Woodruff et al, 2004),

7. controls hypertension by increasing flow rate and increasing the diameter of the vessel (Gabel, 1995), and

8. restores normal pigment in abnormally coloured cutaneous lesions.

Laser therapy also has benefits for patients with Bell's palsy, psoriasis and unhealed donor areas following skin grafting (Baxter et al, 1997). A neodymium:yttrium-aluminumgarnet (Nd:YAG, $1064 \mathrm{~nm}$ ) laser with the correct dosage, as with other lasers, can be used to successfully treat herpes simplex lesions (Ohshiro and Calderhead, 1988).

\section{Phototherapy for superficial wound healing}

The types of wounds that can be mentioned under wound healing not only include pressure sores and ulcers, but also burns, skin donor areas and postoperative wounds (Ohshiro and Calderhead, 1988; Pontinen, 1992; Baxter et al, 1997). Franks and Gilbert (1998) reported rapid demarcation of chronic wounds after initial treatment with clearance of necrotic or sloughy tissue, reduced signs of infection, reduced amount and odour of fluid in highly exuding wounds, reduced pain and resumption of the immune response initiated by the inflammatory phase.

Medrado et al, (2003) evaluated the effects of laser therapy in experimental cutaneous wound healing and concluded that a dose of $4 \mathrm{~J} / \mathrm{cm}^{2}$ was superior to that of $8 \mathrm{~J} / \mathrm{cm}^{2}$. Furthermore, Hawkins and Abrahamse (2005b; 2006a) reported that $5 \mathrm{~J} / \mathrm{cm}^{2}$ using a HeNe laser stimulates mitochondrial activity, which leads to normalization of cell function and ultimately stimulates cell proliferation and migration of wounded fibroblasts to accelerate wound closure 
while a dose of $10 \mathrm{~J} / \mathrm{cm}^{2}$ was associated with a significant amount of cellular and molecular damage. Pereira et al, (2002) studied the effect of a $120 \mathrm{~mW}$ GaAs diode laser on fibroblasts and concluded that $3 \mathrm{~J} / \mathrm{cm}^{2}$ stimulated fibroblast proliferation without impairing procollagen synthesis. Pourzarandian et al, (2005) studied the effect of Er:YAG laser irradiation on cell growth of cultured human gingival fibroblasts and concluded that the optimal stimulative energy density was 3.37 $\mathrm{J} / \mathrm{cm}^{2}$. The results indicate that Er:YAG laser irradiation may benefit wound healing.

A visible light probe $(630-780 \mathrm{~nm})$ has a penetration depth of a few millimetres $(0.5-50 \mathrm{~mm})$ and is used for wound healing and superficial skin conditions (Olsen et al, 1980; Moore et al, 2002). Of four different wavelengths tested $(660 \mathrm{~nm}, 820 \mathrm{~nm}$, $880 \mathrm{~nm}$ and $950 \mathrm{~nm}$ ), Karu et al, (1993) found that $660 \mathrm{~nm}$ was the most effective. A $660 \mathrm{~nm}$ probe followed by a cluster of five $660 \mathrm{~nm}$ diodes is usually recommended for superficial wounds and skin conditions (van Breugal and Dop Bar, 1992). For acne, scar tissue and small lesions a visible red $(660 \mathrm{~nm})$ single point laser probe $(30 \mathrm{~mW})$ is usually recommended. Large cluster probes are usually used for large wounds or burns where the treatment area requires a deeper effect with a reduced treatment time. For wounds at a medium depth the probe is pressed against the skin. The deeper the tissue to be treated the higher the pressure. For open wounds or ulcers, the laser probe is normally held $1-2 \mathrm{~cm}$ from the wound while the periphery is treated with the laser probe in direct contact. The open area of the wound should receive a lower dose than the skin periphery (Tunér and Hode, 2002). A single laser probe $(660 \mathrm{~nm})$ can be used around the wound margin of superficial wounds while a cluster probe (visible red and infra-red laser light) can be used for the soft tissue inflammation. In the treatment of a chronic ulcer for example, a higher dose such as 3-4 $\mathrm{J} / \mathrm{cm}^{2}$ will be used on points along the periphery of the wound followed by a lower dose of $0.5 \mathrm{~J} / \mathrm{cm}^{2}$ over the open wound (Tunér and Hode, 2002; Ohshiro and Calderhead, 1988). The open wound needs a lower dosage than the skin-covered periphery as the laser light is not reflected or scattered but rather absorbed by the skin in the unprotected wound since it hits the uncovered cells directly.

There remains some controversy over whether infected wounds do indeed respond better to laser treatment so special precautions such as holding the probe close (non-contact) to the wound and cleaning the probe with an alcohol wipe have to be used to reduce contamination during laser treatment (Tunér and Hode, 2002; Ohshiro and Calderhead, 1988; Baxter et al, 1997). Nussbaum et al, (2002; 2003) reported that phototherapy using a wavelength of $630 \mathrm{~nm}\left(1-20 \mathrm{~J} / \mathrm{cm}^{2}\right)$ results in bacterial inhibition which may be an important consideration when selecting the correct wavelength for infected wounds (Lucas et al, 2003). An infected ulcer can be treated twice weekly until the infection clears. Patients on prescribed medication or who have conditions known to cause photosensitivity reactions should also avoid LLLT. It is unlikely that a combination of laser and drug will trigger a photosensitivity response however patients should be patch tested with a small dose and examined after 24-48 hours to determine if there is a hypersensitivity reaction.

Acute wounds should be treated daily while chronic wounds should be treated 1-2 times a week (Ohshiro and Calderhead, 1988). When treating through a dark complexion, adipose or highly vascular tissue, more light will be absorbed with reduced penetration to the target tissue, so a greater irradiance will be required in order to achieve the same biological effect (Stadler et al, 2004; Greppi, 2001). Chronic tissue conditions require more treatment intervals where two or three treatments a week are considered as the maximum (Ohshiro and Calderhead, 1988). The deeper the lesion or target tissue the more treatment will be required. It has been shown to be beneficial to treat at closer intervals in the beginning (every other day or every third day for two weeks) and then at longer intervals (once a week for several weeks). As a general rule, it is better to use 3-4 treatments a week with moderate doses than using higher doses and fewer treatments (Tunér and Hode, 2002).

\section{Phototherapy for musculoskeletal pain relief}

Soft tissue injuries such as tendonopathies (tendonitis and tenosynovitis) and ligamentous injuries are easier to treat since the lesions are easier to locate and palpate (Ohshiro and Calderhead, 
1988; Woodruff et al, 2004). Various arthritic conditions have been identified as responding well to laser therapy particularly where osteoarthritis has affected the small joints of the hands and feet (Ohshiro and Calderhead, 1988). Laser therapy provides relief for musculoskeletal pain, postfracture pain, pain at origin or insertion of any muscle or tendon, haematoma, and neurogenic pain (Ohshiro and Calderhead, 1988). Most acute musculoskeletal injuries should be treated daily over a short period whereas chronic musculoskeletal injuries should be treated over a longer period every week if palliative or every 2-3 days if there is low grade inflammation (Tunér and Hode, 2002). Laser therapy has also been indicated for other painful conditions such as shingles (Ohshiro and Calderhead, 1988). Moore et al, (2002) concluded that there was a $50 \%$ reduction in the severity of pain and 50\% reduction in the use of analgesics in patients receiving $24 \mathrm{~J} / \mathrm{cm}^{2}$ per point when compared to the control group. Gaida et al, (2004) showed that $670 \mathrm{~nm}$ laser irradiation of burn scars using $400 \mathrm{~mW}$ twice a week over 8 weeks had a positive effect on the macroscopic appearance, pruritus and pain.

An infra-red probe has a penetration depth of several centimetres and is used for musculoskeletal injuries, acupoints, neurogenic pain and trigger points (Theralase, 2003; Moore et al, 2002). The most frequently used laser for pain therapy is the GaAIAs diode that emits coherent light in the nearinfrared waveband, usually $820-840 \mathrm{~nm}$, and with a continuous wave power output of $60 \mathrm{~mW}$ (Moore et $a l, 2002)$. A near infrared $(810 \mathrm{~nm})$ laser probe can be used to treat pain while a cluster probe can be used for soft tissue inflammation and pain trigger points (muscle, tendon and ligaments). The greatest active depth is achieved when the laser probe is held in direct contact with the skin and the probe is pressed against the skin.

\section{Current and future directions}

In vitro studies currently being performed by the Laser Research Group include investigating the effect of $632.8 \mathrm{~nm}$ HeNe, $830 \mathrm{~nm}$ diode and 1064 nm Nd:YAG laser irradiation on normal, wounded, diabetic and diabetic wounded fibroblast cells. (Hawkins and Abrahamse, 2005a; 2005b; 2006a; 2006b; 2007a; 2007b). The in vitro studies have established important laser variables such as dose $\left(\mathrm{J} / \mathrm{cm}^{2}\right)$ (Hawkins and Abrahamse, 2005b, 2006a), number of exposures (Hawkins and Abrahamse, 2006b) and specific irradiation conditions (Hawkins and Abrahamse, 2007a) that accelerate wound closure, cell-cell communication and cell proliferation and these in vitro results may be used as a guideline for the initiation of a clinical study. Future studies include investigating other conditions of cell stress or damage such as a change in intracellular $\mathrm{pH}$ to mimic metabolic acidosis that is common with diabetes, a reduction in the oxygen tension $\left(\mathrm{p}_{2}\right)$ or hypoxia that is common in chronic inflammation and indolent wounds (Yu et al, 2002) and in vitro ischemia that is common in ischemic heart disease, stroke and hypoxia (Abercrombie, 1966). The results from these in vitro studies will be used to investigate the effect of laser irradiation on a wounded three-dimensional (3D) artificial skin construct. The skin equivalent is a suitable alternative method to animal testing since it represents an advanced alternative to normal cell culture and its natural 3D structure closely reproduces an in vivo situation. In addition, the potential use of laser irradiation on the stimulation of adult adipose derived stem cell differentiation for the use as autologous grafts in wound healing is being investigated.

\section{Conclusion}

Lasers are widely used for pain relief and wound healing without negative or long-term side effects (Theralase, 2003; Coombe et al, 2001). Laser therapy allows the user to combine different probes or cluster heads depending on the laser that is available and the specific application. For example, a $660 \mathrm{~nm}$ probe can be used to treat the periphery of a superficial wound followed by a cluster probe of visible and infrared laser light for the soft tissue and inflammation. The laser treatment parameters can be changed and adapted depending on the type of laser used (visible or infra-red, continuous or pulsed) and the application (acute or chronic). The most important parameter that should be maintained is the dose or the energy density $\left(\mathrm{J} / \mathrm{cm}^{2}\right)$. Factors such as contact or non-contact method and the treatment interval can be modified and adapted according to the specific application and treatment area. 
In order to monitor the effects of the therapy, a record should be kept that includes a comprehensive list of the treatment parameters and documents changes or any signs of improvement (Pontinen, 1992). Laser therapy requires the user to test and retest after the laser therapy to determine if there are any signs of improvement in terms of movement, pain relief or wound healing. Since laser has a systemic effect, it is important to observe caution in interpreting results of studies in which laser has treated one part of the body while another part of the same body has been used as a control (Tunér and Hode, 2002). Some patients require a combination of medications and will respond to LLLT used in combination with other therapeutic modalities. If no improvement is noted after several treatments the therapy should be discontinued. Laser users have reported a good success rate for a wide range of applications in veterinary, health, dentistry (Pourzarandian et al, 2005) and physiotherapy for both wound healing and pain relief. Enwemeka et al, (2004) conducted a meta-analysis on 34 peerreviewed papers and concluded that laser phototherapy is a highly effective therapeutic armamentarium for tissue repair and pain relief. By improving the study design as well as the reporting of all the variables used in trials, laser therapy may become as well recognized as laser surgery. In order to obtain full acceptance as a valid medical modality, new and high quality studies are required (Tunér and Hode, 2002).

\section{ACKNOWLEDGEMENTS}

This project is jointly funded by the University of Johannesburg, National Laser Centre (NLC), National Research Foundation (NRF) and Medical Research Council (MRC).

\section{REFERENCES}

Abercrombie M. and Heaysman J.E.M. (1966) The directional movement of fibroblasts emigrating from cultured explants. Ann Med Exp. Fenn. 44, 161-165.

Allendorf J.D., Bessler M., Huang J., Kayton M.L., Laird D., Nowygrod R., and Treat M.R. (1997) Helium-neon laser irradiation at fluences of 1,2 , and $4 \mathrm{~J} / \mathrm{cm}^{2}$ failed to accelerate wound healing as assessed by both wound contracture rate and tensile strength. Lasers Surg Med. 20(3), 340-345.

Baxter G.D., Diamantopoulos C., O'Kane S. and Shields S. (1997) Therapeutic Lasers Theory and Practice, Churchill Livingstone, New York, N.Y.
Colver G.B. and Priestley G.C. (1989) Failure of helium-neon laser to affect components of wound healing in vitro. British Journal of Dermatology. 121,179-186.

Coombe A.R., Ho C.T. Darendeliler M.A., Hunter N., Philips J.R., Chapple C.C. and Yum L.W. (2001) The effects of low level laser irradiation on osteoblastic cells. Clin Orthod Res. 4(1), 3-14.

de Freitas A.C., Pinheiro A.L.B., Miranda P., Thiers F.A. and Vieira A.L de B. (2001) Assessment of antiinflammatory effect of $830 \mathrm{~nm}$ laser light using C-reactive protein levels. Braz Dent J. 12(3), 187-190.

Dyson M. (2006) Primary, secondary and tertiary effects of phototherapy: a review. Mechanisms of Low Level Light Therapy. Mechanisms for Low-Light Therapy, edited by Michael R. Hamblin, Ronald W. Waynant, Juanita Anders, Proceedings of SPIE Vol. 6140 (SPIE, Bellingham, WA, 2006) 6140, 614005-1 - 614005-12.

Enwemeka C.S., Parker J.C., Dowdy D.S., Harkness E.E., Sanford L.E., and Woodruff L.D. (2004) The efficacy of low power lasers in tissue repair and pain control: a meta-analysis study. Photomed Laser Surg. 22(4), 323-329. Gabel C.P. (1995) Does laser enhance bruising in acute sporting injuries. Aust J Physio. 41(4), 267-269.

Gaida K., Koller R., Isler C., Aytekin 0., Al-Awamin M., Meissi G. and Fry M. (2004) Low level laser therapy - a conservative approach to the burn scar?. Burns. 30(4), 362-367.

Greppi I. (2001) Diode laser hair removal of the black patient. Lasers Surg Med. 28(2), 150-155.

Hamblin M.R., and Deidova, T.N. (2006) Mechanisms of Low Level Light Therapy. Mechanisms for Low-Light Therapy, edited by Michael R. Hamblin, Ronald W. Waynant, Juanita Anders, Proceedings of SPIE Vol. 6140 (SPIE, Bellingham, WA, 2006) 614001-1- 614001-11.

Hawkins D., and Abrahamse H. (2005a) Laboratory methods for evaluating the effect of low level laser therapy (LLLT) in wound healing. African Journal of Biomedical Research. 8, 1-14.

Hawkins D., and Abrahamse H. (2005b) Biological effects of helium-neon (632.8 nm) laser irradiation on normal and wounded human skin fibroblasts. Journal of Photomedicine and Laser Surgery. 23(3), 251-259.

Hawkins D., and Abrahamse H. (2006a) The role of fluence in cell viability, proliferation and membrane integrity of wounded human skin fibroblasts following helium-neon laser irradiation. Lasers in Surgery and Medicine. 38(1), 74-83.

Hawkins D., and Abrahamse H. (2006b) Effect of multiple exposures of Low Level Laser Therapy on the cellular responses of wounded human skin fibroblasts. Journal of Photomedicine and Laser Surgery. 24(6), 715724. 
Hawkins D., and Abrahamse H. (2007a) How long after laser irradiation should cellular responses be measured to determine the laser effect? - An in vitro study. Journal of Laser Applications. 19(1), 1-10.

Hawkins D., and Abrahamse H. (2007b) Changes in cell viability of wounded fibroblasts following laser irradiation in broad-spectrum or infrared light. Laser Chemistry. 2007, 1-10.

Karu T,I., Tiphiova U,A. and Fedoseyeva G.E. (1984) Biostimulating action of low intensity monochromatic visible light: is it possible?. Laser Chemistry 5, 19-25.

Karu T.I. (1989) Photobiology of low power laser therapy. London, Harwood Academic Publishers.

Karu T., Andreichuck T and Ryabykh T. (1993) Suppression of human blood chemi-liminescence by diode laser irradiation at wavelengths 660, 820, 880 and 950 nm. Laser Therapy. 5(2), 103.

Karu T.I. and Kolyakov S.F. (2005) Exact action spectra for cellular responses relevant to phototherapy. Photomedicine and Laser Surgery. 23(4), 355-361.

Kiepeis V.E., Cornell-Bell A. and Trinkaus-Randall V. (2001) Growth factors but not gap junctions play a role in injury induced $\mathrm{Ca}^{2}$ waves in epithelial cells. J Cell Sci. 114(Pt23), 4185-4195.

Kubota J. (2004) Defocused diode laser therapy (830 $\mathrm{nm}$ ) in the treatment of unresponsive skin ulcer: a preliminary trial. J. Cosmet Laser Ther. 6(2), 96-102.

Lucas C., van Gemert M.J. and De Haan R.J. (2003) Efficacy of low level laser therapy in the management of stage Ill decubitus ulcers: a prospective, observer-blinded multicentre randomized clinical trial. Lasers Med Sci. 18(2), 72-77

Matic M., Lazetic B., Poljacki M., Duran V. and lvkovSimic M. (2003) Low level laser irradiation and its effects on repair processes in the skin. Med Pregl. 56(3-4), 137141.

Medrado A.R., Pugliese L.S., Reis S.R. and Andrade Z.A. (2003). Influence of low level laser therapy on wound healing and its biological action upon myofibroblasts. Lasers Surg Med. 32(3), 239-244.

Mendez T.M., Pinheiro A.L., Pacheco M.T., Nascimento P.M. and Ramalho L.M. (2004) Dose and wavelength of laser light have influence on the repair of cutaneous wounds. J. Clin Laser Med Surg. 22(1), 19-25. Moore P., Ridgeway T.D., Higbee R.G., Howard E.W. and Lucroy M.D. (2002) Effect of wavelength on low intensity laser irradiation - stimulated cell proliferation in vitro. Lasers Surg Med. 36(1), 8-12.

Morimoto Y., Arai T., Kikuchi M., Nakajima S. and Nakamura H. (1994) Effect of low intensity Argon laser irradiation on mitochondria respiration. Lasers Surg Med. 15, 191-199.

Nussbaum EL, Lilge L, and Mazzulli T. (2002) Effects of 630-, 660-, 810-, and $905 \mathrm{~nm}$ laser irradiation delivering radiant exposure of $1-50 \mathrm{~J} / \mathrm{cm} 2$ on three species of bacteria in vitro. J Clin Laser Med. and Surg. 20 (6), 325-33

Nussbaum E.L, Lilge, L., and Mazzulli, T. (2003) Effects of low-level laser therapy (LLLT) of $810 \mathrm{~nm}$ upon in vitro growth of bacteria: relevance of irradiance and radiant exposure. J Clin Laser Med Surg. 21(5), 283-90. Ohshiro T., and Calderhead R.G. (1988) Low Level Laser Therapy: A practical introduction. Published by Wiley and Sons, Inc. New York and Brisbane. pp. 17, 28, 29, 30, 33, 34, Olsen J.E., Schimmerling W. and Tobias C.A. (1980) Laser action spectrum of reduced excitability in nerve cells. Brain Res. 204, 436-440.

Peavy G.M. (2002) Lasers and laser-tissue interaction. Vet Clin Small Anim. 32, 517-534.

Pereira A.N., Eduardo Cde. P., Matson E. and Marques M.M. (2002) Effect of low power laser irradiation on cell growth and procollagen synthesis of cultured fibroblasts. Lasers Surg Med. 31(4), 263-267.

Pontinen P.J. (1992) Guidelines for LLLT. Low Level Laser Therapy as a medical treatment modality: A manual for Physicians, Dentists, Physiotherapists and Veterinary surgeons. Pontinen P.J., Eds. 148. Art Urpo Ltd. Tampere, Finland.

Pourzarandian A., Watanabe H., Ruwanpura S.M., Aoki A. and Ishikaw I. (2005) Effect of low level Er:YAG laser irradiation on cultured human gingival fibroblasts. J. Periodontal. 76(2), 187-193.

Rudnick, L. W. (2005) Low intensity laser therapy Too good to be true or a valid scientific form of treatment. http://naturaltherapycenter.com/Lazer/ Accessed date: 12/04/2007.

Schindi A., Schindi M., Pernerstorfer-Schon H., Kerschan K., Knobler R. and Schindi, L. (1999) Diabetic neuropathic foot ulcer: Successful treatment by low intensity laser therapy. Dermatology. 198, 314-317. Smith K. (1991) Light and Life: The photobiological basis of the therapeutic use of radiation from lasers. Progress in Laser Therapy: Selected papers from the October 1990 ILTA Congress. Published by Wiley and Sons, Inc. New York and Brisbane. pp 17.

Stadler I., Lanzafame R., Oskoui P., Zhang R., Coleman J. and Whittaker M. (2004) Alteration of skin temperature during low level laser irradiation at $830 \mathrm{~nm}$ in a mouse model. Photomedicine and Laser Surgery. 22(3), 227-231.

Takac and Stojanovic S. (1998) Diagnostic and biostimulating lasers. Med Pregl. 51(5-6), 245-249. Theralase (2003) Therapeutic laser treatment Laser Theory from designers and manufacturers of therapeutic medical laser systems. http://wwvv.theralase.com/technoloqv.php. Accessed on 
12/04/2007.

Trelles M.A, Mayayo E., Miro L. et al. (1989) The action of low reactive Level Laser Therapy (LLLT) on mast cells: a possible relief mechanism examined. Laser Therapy. 1, 27 -30.

Tunér J. and Hode L., (2002) Laser Therapy - Clinical Practice and Scientific Background. Prima Books AB, Grangesberg, Sweden. Chapter 1. Some basic laser physics. pp. 12, 21, 22, (ISBN: 91-631-1344-9).

van Breugal H.F.I. and Dop Bar P.R. (1992) Power density and exposure time of He-Ne laser irradiation are more important than total energy dose in photobiomodulation of human fibroblasts in vitro. Lasers in Surgery and Medicine. 12, 528-537.

Vladimirovlu. A., Klebanov G.I., Borisenko G.G. and OsipovA.N. (2004) Molecular and cellular mechanism of the low intensity laser radiation effect. Biofizika. 49(2),
339-350.

Woodruff L., Bounkeo J., Brannon W., Dawes K., Barham C., Waddell D. and Enwemeka C. (2004) The efficacy of laser therapy in wound repair: A meta-analysis of the literature. Photomedicine and Laser Surgery. 22(3), 241-247.

Yu A.C.H., Lau A.M.F., Eu A.W.Y., Lau L.T., Lam P.Y., Chen X.Q. and Xu Z.Y. (2002) Changes in ATP and ADP in cultured astrocytes under and after in vitro ischemia. Neurochemical Research. 27(12), 1663-1668. Yu W., McGown M., Ippolito K. and Lanzafame R.J. (1997) Photostimulation of oxidative metabolism and electron chain enzymes in rate liver mitochondria. Photochem. Photobiol. 66, 866-871. 